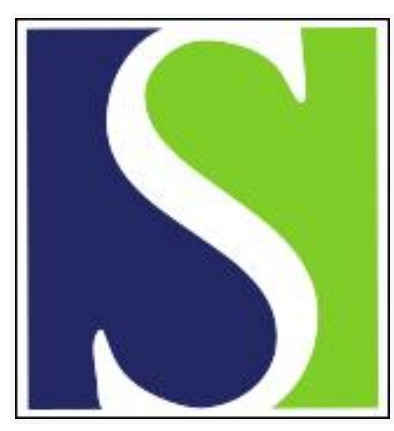

Scand J Work Environ Health 1978;4(4):284-294

https://doi.org/10.5271/sjweh.2697

Issue date: Dec 1978

\title{
Sputum cytology of asbestosis patients.
}

by Huuskonen MS, Taskinen E, Vääränen V

Key terms: asbestosis; asbestosis patient; benign atypia; bronchogenic carcinoma; dysplasia; ferruginous body; sputum cytology

This article in PubMed: www.ncbi.nlm.nih.gov/pubmed/734389

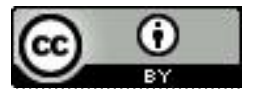




\title{
Sputum cytology of asbestosis patients
}

\author{
by MATTI S. HUUSKONEN, M.D., EERO TASKINEN, M.D., \\ and VESA VAARANEN, M.D. ${ }^{1}$
}

\begin{abstract}
HUUSKONEN, M. S., TASKINEN, E. and VAARANEN, V. Sputum cytology of asbestosis patients. Scand. j. work environ. \& health 4 (1978) 284-294. One hundred and fourteen patients with asbestosis, $59 \%$ of whom were chronic cigarette smokers, were subjected to a cytological sputum examination which showed: 36 workers $(31.6 \%)$ with squamous metaplasia, $20(17.5 \%)$ with benign columnar cell atypia, $5(4.4 \%$ ) with benign dysplasia, 2 with suspicious cells for carcinoma, and 1 with anaplastic (microcellular) carcinoma. Clinically and histologically five lung cancers were verified, two of which were cytologically false negatives. All asbestosis patients with lung cancer were chronic smokers. Of the 114 asbestosis patients, $49(43.0 \%)$ had ferruginous bodies in their sputum. The workers from an asbestos quarry more frequently had ferruginous bodies in their sputum specimens than the other patients. Radiographically moderate and severe asbestosis cases showed squamous metaplasia more frequently than those with radiographically slight asbestosis. Most of the detected cellular atypias represented reversible alterations of the respiratory epithelium. It is, however, important to screen the sputum of older ( $>40$ years of age) smoking asbestos workers with benign and suspicious cellular atypias regularly because these alterations may represent the first step in the pathway to bronchogenic cancer. The results of this study did not answer the question of whether bronchial cancer of patients with asbestosis is curable if detected early with cytological methods.
\end{abstract}

Key words: asbestosis, benign atypia, bronchogenic carcinoma, dysplasia, ferruginous bodies, sputum cytology.

The worst pulmonary complications found in asbestos workers are asbestosis, lung cancer, and malignant mesothelioma, the peak incidences of all of which occur approximately 15 to 30 years after the onset of exposure (20). Smoking asbestos workers have a 17 to 90 times greater chance of developing lung cancer than noncigarette smoking, nonasbestos workers (14, 20). Although the increased occurrence of adenocarcinoma in conjunction with asbestosis has been stressed by several authors

\footnotetext{
1 Department of Occupational Medicine, Institute of Occupational Health, Helsinki, Finland.
}

Reprint requests to: Dr. M. S. Huuskonen, Institute of Occupational Health, Haartmaninkatu 1, SF-00290 Helsinki 29, Finland.
$(7,8,21,24)$, other histological types of lung carcinoma are also encountered (12).

The development of bronchogenic carcinoma following exposure to carcinogens has been observed to consist of a series of gradual changes. In the bronchial epithelium it usually starts with squamous cell metaplasia, which is initially quite regular, but with the passage of time cellular changes appear that reflect atypical metaplasia. These changes become progressively more severe until carcinoma is manifest. The progressive changes from metaplasia to carcinoma are widely accepted as the route to epidermoid carcinoma $(1,15,18,23)$. Whether or not they sometimes lead to small-cell, undifferentiated carcinoma is uncertain. 
For many years sputum cytology has been useful in detecting and diagnosing lung carcinoma in its early stages; it has yielded positive results in up to $90 \%$ of the cases $(11,13)$. The aim of this study was to determine cytologically the prevalence and nature of bronchial epithelium atypia among Finnish asbestosis patients, as well as to determine the presence of malignancy and ferruginous bodies and their relationship to asbestos exposure.

\section{SUBJECTS AND METHODS}

Of the asbestosis patients diagnosed by the Institute of Occupational Health between 1964 and 1976, 114 were reexamined for this study. Occupation, sex, age, year and age at the time of entry into jobs exposed to asbestos, duration of asbestos exposure, and smoking habits were accounted for. Subjects who had not smoked in the ten years prior to the investigation were considered nonsmokers. All others were listed as smokers. A clinical investigation including chest radiographs was made.
The subjects had worked in the insuladion industry (as insulators or asbestos sprayers), in an asbestos cement product factory, in an asbestos quarry, or in some other industry, including shipbuilding, etc. Their occupational history is summarized in tables 1,2 and 3.

In this study the diagnostic criteria of asbestosis were history of occupational exposure to asbestos dust and positive radiographic findings of small diffuse pulmonary opacities rated according to the ILO-U/C International Classification of Pneumoconiosis (9). Additional supporting features included dyspnea caused by effort, persistent basal crepitations, clubbing of fingers, and reduction in vital capacity, forced expiratory volume in $1 \mathrm{~s}$ or the single breath carbon-monoxide transfer factor, but these findings were not used as obligatory diagnostic criteria.

Three consecutive morning specimens of sputum were collected from each subject, the first usually in the clinic and the other two at home. All sputa were fixed directly into $70 \%$ alcohol. Two smears prepared from each subject were stained according to the Papanicolaou method. Preliminary screening was performed by a laboratory technician who recorded all the useful findings. The final report was made by a cytopathologist (E.T.). The cytological

Table 1. Occupation, number, sex, and age (at the time of the examination) of the subjects.

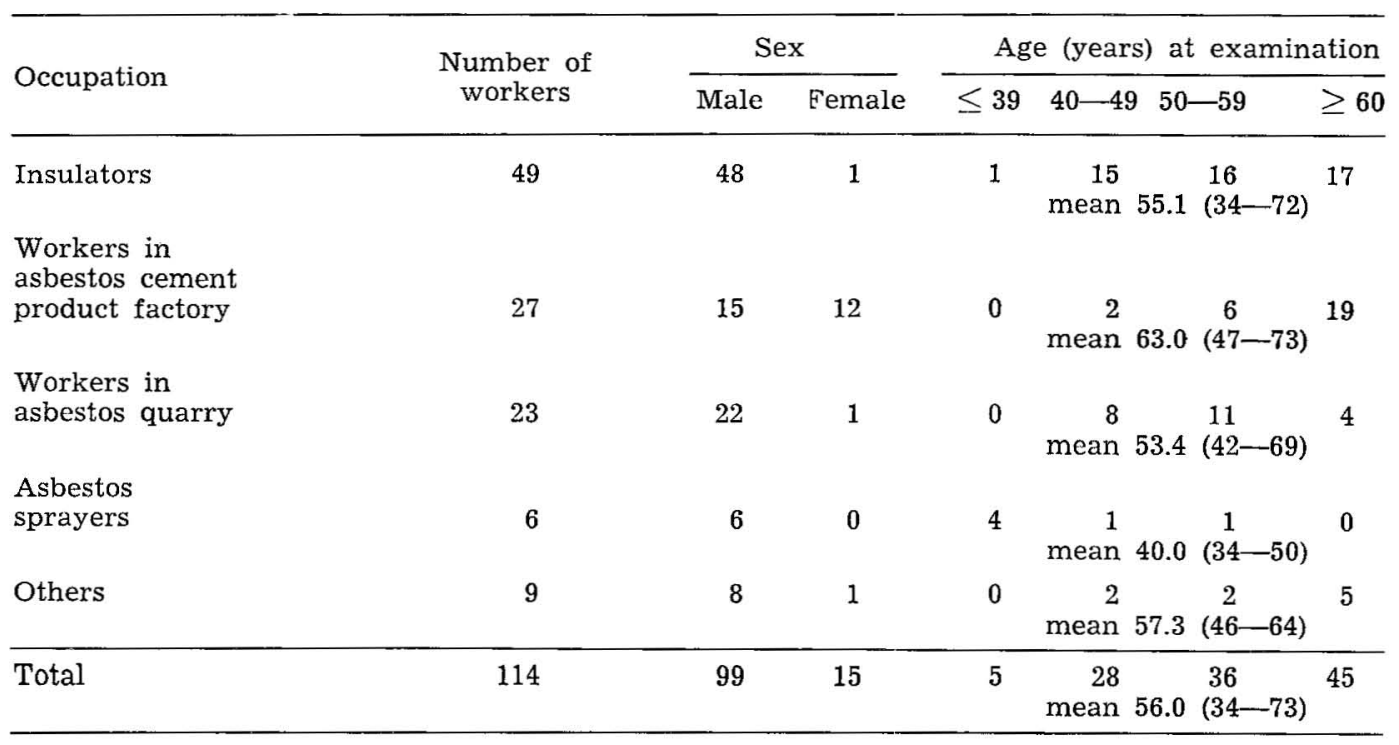


findings were reported according to the

identified before a smear was considered classification of Papanicolaou, i.e., class ${ }^{i} \bar{b}$ adequate; otherwise it was presumed to be to V. Free alveolar macrophages had to be insufficient (Papa cl 0).

Table 2. Year of entry and age at entry into asbestos work.

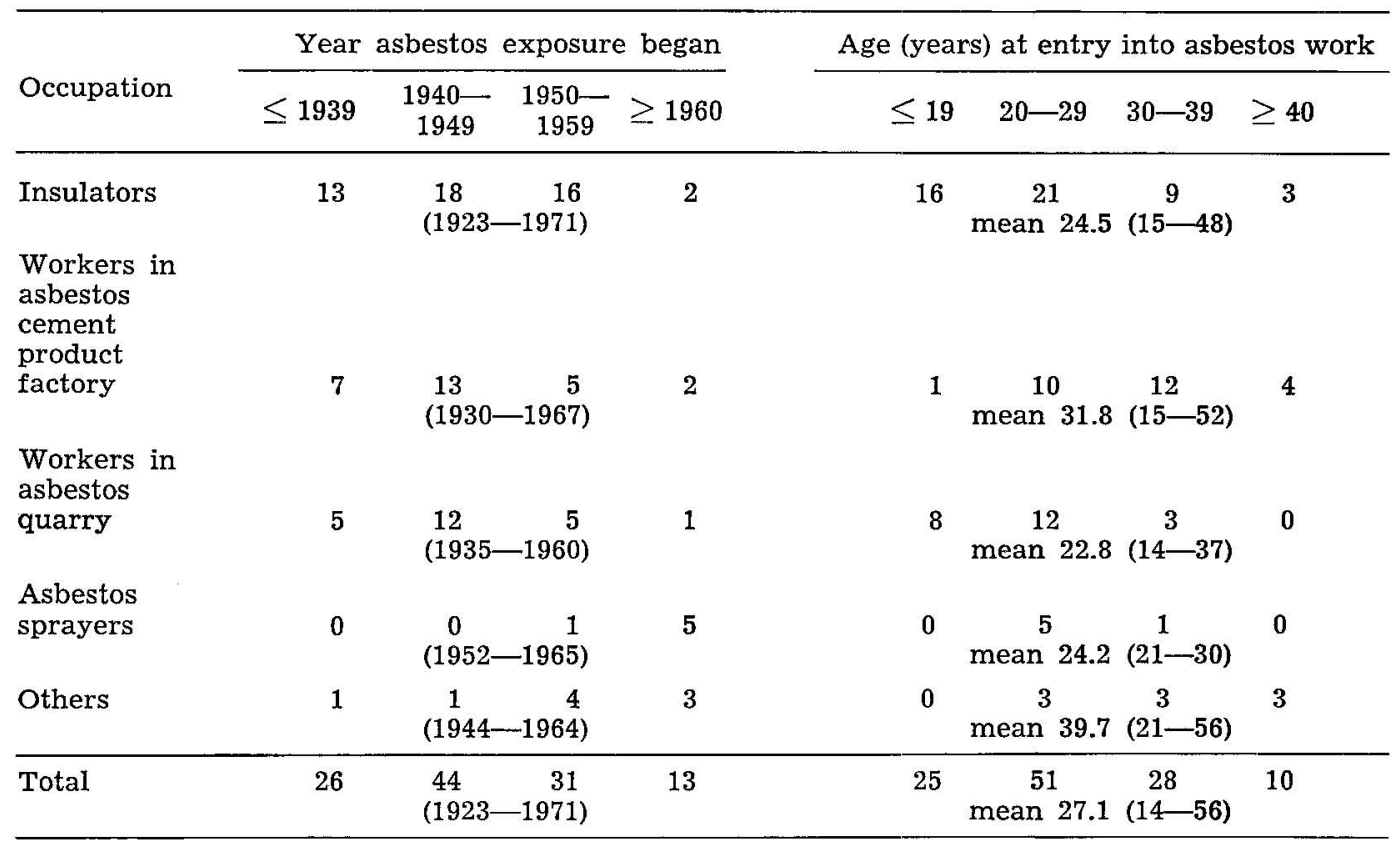

Table 3. Length of asbestos exposure and smoking habits.

\begin{tabular}{|c|c|c|c|c|c|c|}
\hline \multirow{2}{*}{ Occupation } & \multicolumn{4}{|c|}{ Length of exposure (years) } & \multirow{2}{*}{ Smokers } & \multirow{2}{*}{ Nonsmokers } \\
\hline & $\leq 9$ & $10-19$ & $20-29$ & $\geq 30$ & & \\
\hline Insulators & 2 & $\begin{array}{c}11 \\
\text { mean }\end{array}$ & $\stackrel{21}{(5-44)}$ & 15 & 31 & 18 \\
\hline \multicolumn{7}{|l|}{$\begin{array}{l}\text { Workers in } \\
\text { asbestos } \\
\text { cement } \\
\text { product }\end{array}$} \\
\hline factory & 6 & $\begin{array}{c}4 \\
\text { mean }\end{array}$ & $(5-40)$ & 6 & 19 & 8 \\
\hline \multicolumn{7}{|l|}{$\begin{array}{l}\text { Workers in } \\
\text { asbestos }\end{array}$} \\
\hline quarry & 2 & $\begin{array}{c}6 \\
\text { mean }\end{array}$ & $\begin{array}{c}11 \\
(5-35)\end{array}$ & 4 & 13 & 10 \\
\hline $\begin{array}{l}\text { Asbestos } \\
\text { sprayers }\end{array}$ & 1 & $\begin{array}{c}4 \\
\text { mean }\end{array}$ & $\begin{array}{c}1 \\
(6-24)\end{array}$ & 0 & 4 & 2 \\
\hline Others & 2 & $\stackrel{4}{\text { mean }}$ & $\begin{array}{c}2 \\
(3-32)\end{array}$ & 1 & 7 & 2 \\
\hline Total & 13 & $\begin{array}{c}29 \\
\text { mean }\end{array}$ & $\begin{array}{c}46 \\
(3-44)\end{array}$ & 26 & 74 & 40 \\
\hline
\end{tabular}


Table 4. Radiographic severity of the diffuse pulmonary fibrosis and the occurrence of crepitations and finger clubbing.

\begin{tabular}{|c|c|c|c|c|c|c|c|}
\hline \multirow{2}{*}{ Occupation } & \multicolumn{3}{|c|}{ Radiographs a } & \multicolumn{2}{|c|}{ Crepitations } & \multicolumn{2}{|c|}{ Finger clubbing } \\
\hline & 0 & 1 & 2 & Yes & No & Yes & No \\
\hline Insulators & 23 & 20 & 6 & 22 & 27 & 16 & 33 \\
\hline $\begin{array}{l}\text { Workers in } \\
\text { asbestos } \\
\text { cement } \\
\text { product } \\
\text { factory }\end{array}$ & 11 & 8 & 8 & 19 & 8 & 7 & 20 \\
\hline $\begin{array}{l}\text { Workers in } \\
\text { asbestos } \\
\text { quarry }\end{array}$ & 10 & 11 & 2 & 14 & 9 & 6 & 17 \\
\hline $\begin{array}{l}\text { Asbestos } \\
\text { sprayers }\end{array}$ & 1 & 5 & 0 & 4 & 2 & 3 & 3 \\
\hline Others & 6 & 2 & 1 & 7 & 2 & 3 & 6 \\
\hline Total & 51 & 46 & 17 & 66 & 48 & 35 & 79 \\
\hline
\end{tabular}

a $0=$ profusion of small opacities $0 / 1,1 / 0$ or $1 / 1 ; 1=$ profusion of small opacities $1 / 2,2 / 1$ or $2 / 2 ; 2=$ profusion of small opacities $2 / 3$ or more.

We also recorded the inflammation and eosinophils found in the sputum specimens. The presence of inflammation was recorded cytologically when sputum smears revealed a marked representation of neutrophils in comparison with cells. When this relation was extremely clear, the cellular picture was interpreted as purulent inflammatory finding. The estimation of red cells was hampered by acidophilic material, thought to be either degenerated red cells or proteinaceous material.

The total number of ferruginous bodies per slide was estimated as follows: few: 1 to 5 ; moderate: 6 to 15 ; many: 16 or more.

Benign atypias (Papa cI II) included columnar cell atypia, squamous cell metaplasia and benign dysplasia. The term dysplasia was used to imply dyskaryosis or atypical metaplasia. Suspicious atypias (Papa cl III) included moderate to severe dysplasia, as well as all the suspicious cellular alterations for which malignancy could not be confirmed or excluded. Findings for malignancy included cells originating from in situ and invasive carcinoma.

Thirty-three of the subjects had also had a sputum examination made seven years earlier.
The statistical analyses were made with the chi-square test and, in comparisons of small frequencies, with Fisher's exact probability test.

\section{RESULTS}

The clinical and radiographic results are summarized in table 4 , and the cytological findings are presented in table 5. Ten patients $(8.8 \%)$ had insufficient sputum specimens. The most characteristic cytological feature of sputum smears from asbestosis patients seemed to be the abundance of alveolar macrophages.

\section{Malignant and suspicious cytological findings}

Altogether five pulmonary malignant neoplasms were verified histologically or clinically in this material. They included one small-cell anaplastic (microcellular), one large-cell anaplastic, one epidermoid 
Table 5. Cytological findings.

\begin{tabular}{lll}
\hline Cellular finding & $\begin{array}{c}\text { Number } \\
\text { of } \\
\text { subjects }\end{array}$ & $\%$ \\
\hline
\end{tabular}

No sign of cellular atypia

(Papa cl I)

40

Benign atypia

(Papa cl II)

61

Suspicious atypia

(Papa cl III)

Malignant findings

(Papa cl IV-V)

Inflammatory finding

Purulent inflammatory finding

Ferruginous bodies

Eosinophils

Insufficient specimens
The patient with positive sputum cytology was a 66-year-old man with a 25-year smoking history ( 20 cigarettes/d). He had been employed in an asbestos cement product factory for 14 years (1959-1973). Sputum smears revealed malignant cells of microcellular carcinoma (fig. 1), together with an inflammatory finding, red cells, and a moderate number of ferruginous bodies. Seven years earlier sputum specimens had disclosed no atypia. Chest radiographs showed bilateral diffuse pulmonary fibrosis, especially in the lower lobes ( $\mathrm{s} 1 / 2$ ), bilateral pleural thickening (c 2), and calcifications in both walls and in the left diaphragm (gr 2). In the left lower lobe there was a localized lesion. The routine studies were negative for metastases, and therefore left exploratory thoracotomy and resection of the left pulmonary lower lobe was performed. Histological examination confirmed the microcellular carcinoma and disclosed metastases in the mediastinal lymph nodes. Radiation therapy was given the patient. However, five months after the operation he died.

The first patient with suspicious sputum cytology was a 55-year-old insulator with a 40 year smoking history (20 cigarettes/d). He had insulated for 27 years (1941-1968). His sputum specimens revealed cells suspicious of microcellular carcinoma, together with an inflammatory finding and many ferruginous bodies. Chest radiographs showed bilateral diffuse pulmonary fibrosis ( $\mathrm{p} 2 / 2$ ), especially in the lower lobes, bilateral pleural thickening (c 2), ill-defined right diaphragm and cardiac outline (3), and calcifications in both walls and in others ( $\mathrm{gr} 3$ ). Radiography revealed emphysema and honeycombing too, but no localized lesion. Three months later, in another clinic, sputum specimens disclosed malignant cells of microcellular carcinoma, and there was also a localized lesion in the lower lobe findings suspicious of malignancy.

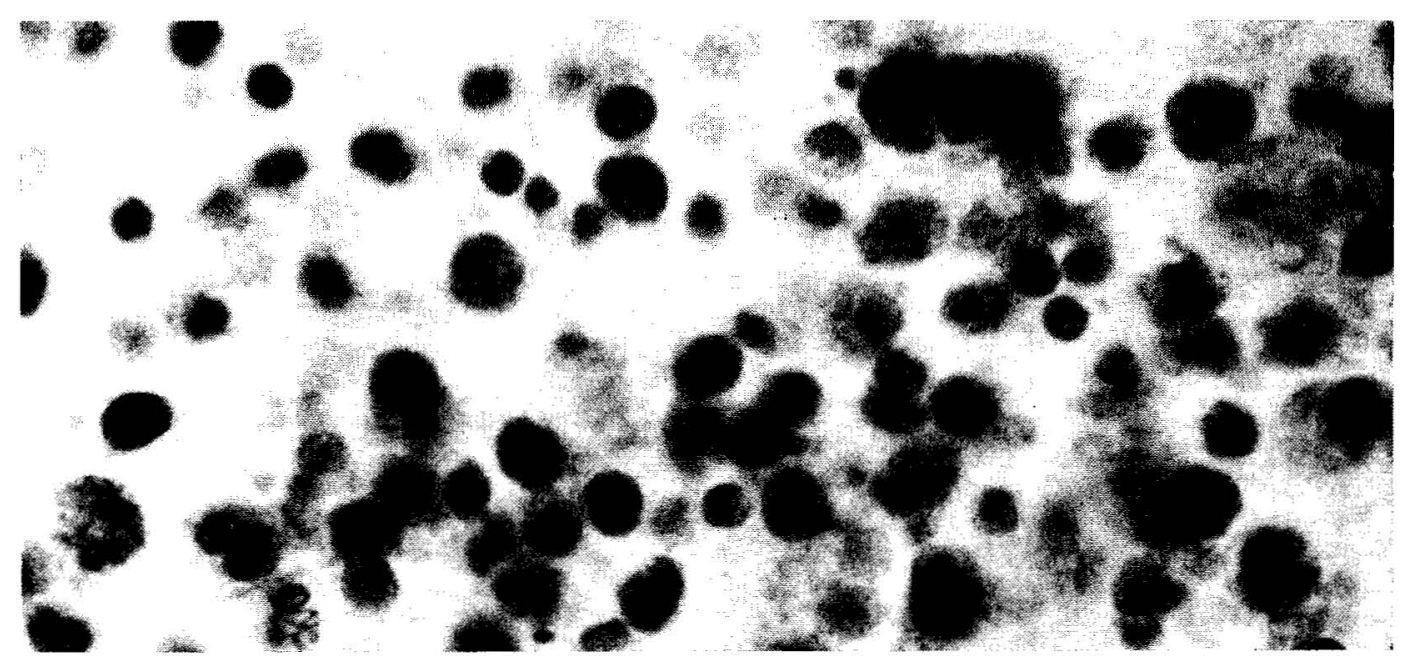

Fig. 1. Small malignant cells, leucocytes, macrophages and red blood cells in a sputum specimen. Microcellular carcinoma. Papanicolaou cl. V. Papanicolaou staining $\times 1500$. 
of the right lung. Because of the markedly decreased ventilatory capacity, radiation and chemotherapy were given the patient. He died of bronchogenic carcinoma 15 months after the finding of suspicious sputum cytology.

The second patient with suspicious sputum was a 59-year-old engineer with a 16-year (1942-1958) smoking history (20 cigarettes/ d). He had worked as an engineer for 11 years in an asbestos quarry (1943-1953) and then as a manager of an asbestos cement product factory for 15 years (1954-1969). His first sputum examination in 1969 revealed a purulent inflammatory finding, ferruginous bodies, and squamous metaplasia. Seven years later sputum specimens disclosed cells suspicious of adenocarcinoma, together with a purulent inflammatory finding and red cells. Chest radiographs showed typical findings of asbestosis with bilateral lower lobe diffuse fibrosis (s 2/1), left pleural thickening (c 2), and ill-defined right and left diaphragms and cardiac outline (3), but there were no calcifications or localized lesions. The patient refused bronchoscopy or other invasive investigations. Chest radiographs and sputum specimens were controlled once every three months. Eleven months after his first visit in 1976 he developed pneumonia. At that time the sputum examination revealed cells suspicious of epidermoid carcinoma, and chest radiographs showed a suspicious infiltration in the lower lobe of the left lung. Left exploratory thoracotomy and resection of the left lung was performed. A tumor the size of an orange was found in the lower lobe of the left lung, and five small tumors in the upper lobe of the left lung. The histological diagnosis was anaplastic carcinoma, including features of adenocarcinoma. No metastases were found. Radiation therapy was given the patient. However, three months after the operation he died.

No false positive findings were found in this study.

\section{False negative results}

Two of the five pulmonary malignant neoplasms remained cytologically false negative.

The first false negative case was a 65-year-old woman with a 34-year smoking history (about 15 cigarettes/d). She had been employed in an asbestos cement factory for nine years $(1940-1949)$ as a spinner. Sputum smears revealed eosinophils and a few ferruginous bodies, but no atypia. Chest radiographs showed bilateral, especially lower lobe, diffuse pulmonary fibrosis (t $2 / 2$ ), but no pleural changes. Emphysema and honeycombing were also found. In the right lower lobe there was a localized lesion $(4 \times 3 \mathrm{~cm})$. A transthoracic, fine-needle aspiration biopsy performed in another clinic revealed malignant cells of epidermoid carcinoma. She refused an operation and entered radiation therapy.

The second false negative case was a 50 year-old man with a 30-year smoking history (20 cigarettes/d). He had been employed in an asbestos cement product factory for 25 years (1942-1967) as a sawer of asbestos cement products. After that he had a firm of his own making roofs from asbestos plates. Sputum specimens revealed an inflammatory finding and red cells, but no atypia. Chest radiographs showed diffuse pulmonary fibrosis bilaterally in the lower lobe (s 3/4), ill-defined right and left diaphragms and cardiac outline (3), calcifications in both walls and diaphragms (gr 3), and emphysema, but no localized lesion. Three months later he got pneumonia and hemoptysis and was again studied cytologicalIy in another clinic. Cells suspicious of anaplastic carcinoma were found, and a chest radiograph showed a localized lesion in the upper right lobe. Right exploratory thoracotomy and resection of the right lung was performed. The histological diagnosis confirmed large-cell anaplastic carcinoma and revealed visceral metastases. The patient died three months after the operation.

Some of the subjects refused to give sputum specimens. One of these was a 51-year-old man with a 27-year (1944-1971) smoking history of about 10 cigarettes/d. He had been employed in an asbestos quarry for 15 years $(1955-1956$ and $1960-1973)$ in various other jobs. Chest radiographs showed bilateral, especially lower lobe, diffuse pulmonary fibrosis (t 1/2), bilateral pleural thickening (c 2), ill-defined cardiac outline (1), and calcifications in both walls and diaphragms and others ( $\mathrm{gr} 3$ ). There was a localized lesion in the lower lobe of the right lung, and right exploratory thoracotomy and resection of the right lower lobe was performed. The histological examination disclosed a malignant hemangiopericytoma and metastases in the right hilus. Radiation and chemotherapy were given the patient.

\section{Benign atypias}

Of the 114 asbestosis patients, $61(55.3 \%)$ had benign atypias in their sputum, the majority of which were squamous metaplasia $(36 / 114=31.6 \%)$. Other cellular alterations included benign columnar cell atypia $(20 / 114=17.5 \%)$ and dysplasia $(5 / 114=4.4 \%)$ (fig. 2$).$ In another Finnish material (Taskinen, unpublished data) $45 \%$ of the asbestos workers had benign atypia; this prevalence was twice that of benign atypia among nonexposed controls.

The asbestosis cases were divided into three groups according to the radiographic appearances (Rtg $0=$ profusion of small pulmonary opacities $<1 / 2$; Rtg $1=$ profusion of opacities from $1 / 2$ to $2 / 2$; and 

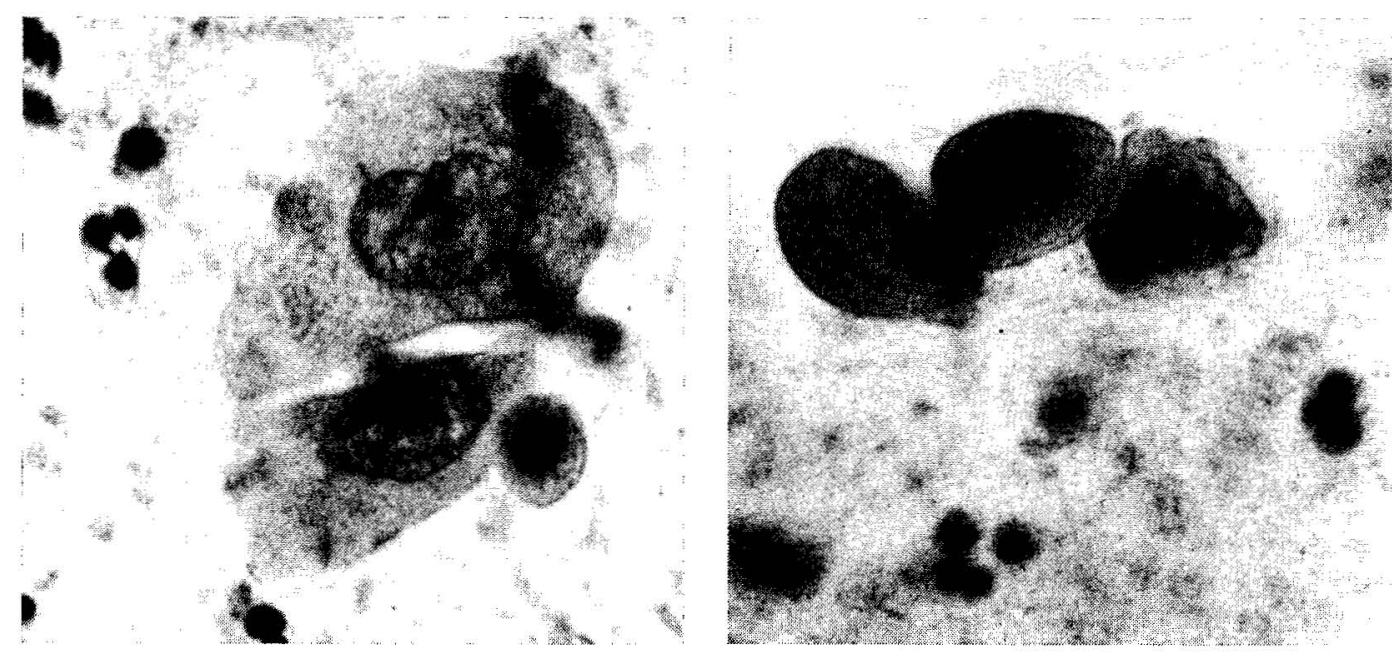

Fig. 2. Dysplastic cells in a sputum smear. Papanicolaou cl. II. H \& E staining $\times 1500$.

$R \operatorname{tg} 2=$ profusion of opacities $2 / 3$ or more). Benign columnar cell atypia was not related to the radiographic severity of asbestosis. The prevalence of squamous metaplasia was low in radiographically slight asbestosis (Rtg $0, \mathrm{~N}=11 / 52$ ) when compared to the level found in radiographically moderate and severe cases (Rtg $1+2, N=25 / 62$ ). The chi-square test result was $3.96(p<0.05)$. Benign dysplasia had no relationship with radiographic profusion of diffuse pulmonary fibrosis. Neither were smoking habits, length of exposure or occupation related to any form of benign atypia.

\section{Ferruginous bodies}

Of the 114 patients with asbestosis, 49 $(43.0 \%)$ had ferruginous bodies in their sputum (fig. 3). In another Finnish material the presence of ferruginous bodies was $1.4 \%$ among nonexposed referents and $36.0 \%$ among asbestos workers (Taskinen, unpublished data). The average length of the ferruginous bodies was $55 \mu(12-190)$. Thirty patients had few, fifteen moderate, and four many ferruginous bodies in their specimens. Of the 19 patients with moderate and many ferruginous bodies, two had either suspi-

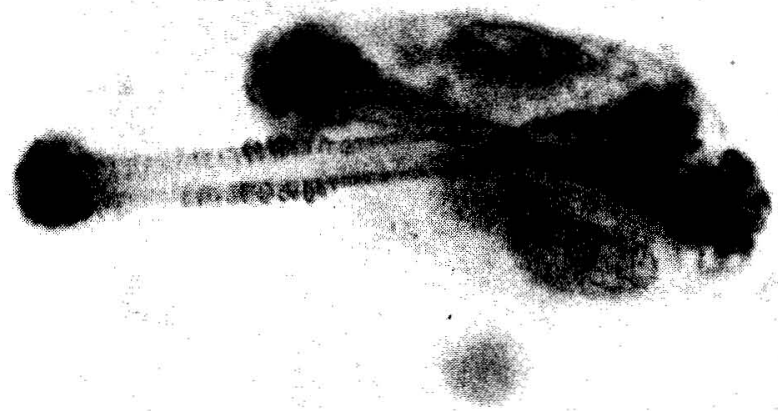

Fig. 3. Two ferruginous bodies engulfed by a macrophage in a sputum smear. Papanicolaou staining $\times 1500$. 
Table 6. Presence of ferruginous bodies in sputum.

\begin{tabular}{lccc}
\hline Occupation & $\begin{array}{c}\text { Number } \\
\text { of } \\
\text { workers }\end{array}$ & $\begin{array}{c}\text { Number of workers } \\
\text { with ferruginous } \\
\text { bodies in their } \\
\text { sputum }\end{array}$ & \% \\
\hline $\begin{array}{l}\text { Insulators } \\
\begin{array}{l}\text { Workers in } \\
\text { asbestos cement } \\
\text { product factory }\end{array}\end{array}$ & 49 & 21 & 42.9 \\
$\begin{array}{l}\text { Workers in } \\
\text { asbestos quarry }\end{array}$ & 27 & 7 & 25.9 \\
$\begin{array}{l}\text { Asbestos } \\
\text { sprayers }\end{array}$ & 23 & 15 & 65.2 \\
Others & 6 & 4 & 66.7 \\
\hline Total & 9 & 2 & 22.2 \\
\hline
\end{tabular}

cious dysplasia or malignant cells in their sputum. The number of ferruginous bodies had no relationship with the length of exposure or the year of entry into an occupation with exposure to asbestos dust.

The radiographic severity of asbestosis, the smoking habits and the length of exposure had no relationship with the presence of ferruginous bodies in sputum. Patients from the asbestos quarry more frequently had ferruginous bodies in their sputum smears than the workers in the other groups $\left(\chi^{2}=9.31, \mathrm{p}<0.01\right)$ (table 6 ).

\section{Inflammatory findings}

Of the 114 asbestosis patients, $89(78.1 \%)$ had cellular findings indicating inflammation in their sputum specimens. An inflammatory finding was less frequent in cases with radiographically slight asbestosis than in those with moderate or severe asbestosis ( $R \operatorname{tg} 0 / R \operatorname{tg} 1, \chi^{2}=4.83, \mathrm{p}<0.05$; Rtg $0 / R \operatorname{tg} 2, \chi^{2}=3.54, \mathrm{p} \sim 0.06$; Rtg $0 / R \operatorname{tg}$ $1+2, \chi^{2}=7.15, \mathrm{p}<0.01$ ). Smoking habits, length of exposure, and occupation were not related to the presence of findings indicating inflammation in the bronchial tree.

\section{Eosinophils}

A total of $23(20.2 \%)$ of the 114 asbestosis patients had eosinophils in their sputum smears. Neither the severity of radiographic asbestosis nor the length of exposure had any relationship with the presence of eosinophils in the specimens. Smokers tended to have an increased prevalence of eosinophils in their sputum in comparison to nonsmokers $\left(\chi^{2}=3.57\right.$, $\mathrm{p} \sim 0.06$ ). Workers from an asbestos quarry had an increased prevalence of eosinophils in their sputum specimens when compared to workers in other occupations $\left(\chi^{2}=10.40 ; \mathrm{p}<0.01\right)$.

\section{Follow-up study}

Thirteen workers from an asbestos cement product factory and 20 from an asbestos quarry had had their first sputum examination made in 1969, i.e., seven years earlier. Three showed a clear progression from normal or metaplastic cells to dysplastic or malignant cells. In 30 cases there was no clear trend toward the development of cellular atypias.

One worker from the asbestos cement product factory had no atypia in the first examination, but the present sputum specimens revealed cells indicating microcellular carcinoma. In another case the first examination showed squamous metaplasia and the present one cells suspicious of epidermoid carcinoma. One asbestos quarry worker had no atypia in the first examination and benign dysplasia in the reexamination. 


\section{DISCUSSION}

Greenberg et al. (6) found 2 carcinomas $(0.4 \%)$ and 18 cases of severe atypia $(3.2 \%)$ among 554 former asbestos workers. Our cytological findings roughly equaled these results, but the presence of malignancy was surprisingly high. Among the 114 asbestosis patients, five lung carcinomas were confirmed clinically or histologically. The distribution of the histological types of the four microscopically verified malignant cases is also interesting: one large-cell anaplastic, one small-cell anaplastic, one epidermoid and one mixed-type with anaplastic and adenomatous features. This variation may indicate that the multiplicative carcinogenetic effect of asbestos and smoking that is claimed to occur in distal airways (24) may also take place in the more central parts of the bronchial tree. Adenocarcinoma did not appear to be overrepresented in this study, but the material was too small for any definitive conclusions to be drawn.

Of the five confirmed carcinomas, cytological examination disclosed one malignant neoplasm, two were suspected, and two were missed. The first of the false negative cases showed a rather large tumor radiographically, and it is possible that the tumorous mass obstructed the lumen of the bronchus and thus prohibited the exfoliation of malignant cells. This mechanism has been found to be one of the most common reasons for false negative findings (22). The other false negative case had radiographically severe asbestosis (s 3/4). The restriction caused by the fibrosis may explain the poor cellular yield and false negative findings.

No false positive cases were found in this cytological examination. Two of the patients with lung cancer had also had a sputum analysis made seven years earlier. In the present examination one of them had anaplastic, microcellular carcinoma known to be rapid in its development (5). It is possible therefore that in 1969 this man had no bronchogenic malignancy. The other patient had anaplastic carcinoma including adenomatous features. In 1969 his sputum examination revealed squamous metaplasia, a purulent inflammatory finding, and ferruginous bodies. Ana- plastic cancer can develop rather quickly, whereas the development of adenomatous carcinoma is known to be slow (5). It may be that purulent inflammatory cells in his previous sputum overshadowed the other constituents, including the atypical cells, and thus resulted in a false negative finding.

Greenberg et al. (6) detected squamous metaplasia in $42 \%$ and benign dysplasia in $8 \%$ of 554 former asbestos workers. Our results were 31.6 and $4.4 \%$, respectively. In addition we found columnar cell atypia in $17.5 \%$ of the patients. Asbestos exposure appeared to increase the prevalence of benign atypia. Squamous metaplasia in this study was less frequent in the sputum of patients with radiographically slight findings than in those with radiographically moderate and severe asbestosis. It may be that in asbestosis the cellular alterations of the bronchial epithelium progress as the disease advances. Special attention should be paid to dysplasia or atypical metaplasia. This category may include cellular alterations of two different characters: (a) a degenerative form induced by an inflammatory process or (b) proliferative dysplasia in connection with bronchogenic cancer (4). The former is a reversible lesion which may subside when the primary reaction has been eliminated. Proliferative dysplasia, although microscopically often benign, may have a neoplastic nature and may therefore already be irreversible. In addition these two cellular changes cannot always be distinguished morphologically. Patients with dysplastic cytological findings have to be the objects of special follow-up.

It is surprising that the smoking habits in this material appeared to have no effect on the prevalence of benign cellular atypia, possibly either because of the small size of the material or the fact that the heavy effect of asbestos exposure overshadowed the influence of smoking.

Greenberg et al. (6) reported the presence of ferruginous bodies in $33 \%$ of former asbestos workers. Taskinen found ferruginous bodies in $36.0 \%$ of the asbestos workers in a Finnish series and in $1.4 \%$ of nonexposed referents. In this study ferruginous bodies were found in $43.0 \%$ of the patients. Greenberg et al. 
(6) reported that the yield of these bodies is about three times greater in aerosolinduced specimens than in three consecutive morning specimens of sputum. Ferruginous bodies seem to appear in the sputum already after a few months of asbestos exposure. In contrast to the findings of Farley et al. (2), no positive relationship between the occurrence of ferruginous bodies and the length of occupational exposure to asbestos dust could be found in the present study. The workers from an asbestos quarry had ferruginous bodies in their sputum more often than the other workers; this finding may indicate heavy exposure in the asbestos quarry. The quantity of ferruginous bodies in the asbestos sprayers was high. But the number of asbestos sprayers was small, and therefore no significant difference was found in comparison to the other groups. In agreement with Farley et al. (2), we concluded that the presence of ferruginous bodies in sputum smears seems to indicate only that the individual has been exposed to asbestos dust.

The quality of asbestos varied in different occupations. Asbestos sprayers were exposed to crocidolite, and asbestos quarry workers to anthophyllite. In other occupations the asbestos exposure was mixed, consisting mainly of chrysotile and, in smaller amounts, an thophyllite, crocidolite and amosite. The quality of asbestos, according to occupation, had no significant effect on cellular atypias or the presence of an inflammatory finding and ferruginous bodies.

The number of insufficient specimens was not very high $(8.8 \%)$ in this study. The manner in which the sputum specimens were collected may have had some effect (10). Sputum collected by aerosol inhalation during the initial clinic visit could be a solution. According to Greenberg et al. (6) atypical and malignant cells are equally distributed between aerosol-induced and three consecutive morning specimens. Diffuse pulmonary fibrosis with restrictive impairment might also be a factor which increases the number of insufficient specimens.

Sputum cytology is useful in monitoring asbestos workers because it detects a lesion of the bronchial epithelium at an early stage of neoplastic development, and a successful cancer operation may be expected at this stage $(16,25)$. Before invasive carcinomas develop, there appears to be an interval during which individuals exfoliate cells that are markedly atypical or represent carcinoma in situ in their sputum (19). This is just the period in which cytological examination of the sputum has been found to show its advantages for the early detection of bronchogenic cancer. Serial chest radiographs do not truly promote the early detection of lung cancer (3). However some authors do not agree that treatment results are improved in cases that are detected early with cytological methods and are subsequently operated on, but they consider the prognosis nearly similar to conservatively treated cases (17). The results of this study did not answer the question of whether bronchial cancer of patients with asbestosis is curable if detected early with cytological methods.

\section{REFERENCES}

1. AUERBACH, O., STOUT, A. P., HAMMOND, E. C. and GARFINKEL, L. Changes in bronchial epithelium in relation to cigarette smoking and in relation to lung cancer. N. engl. j. med. 265 (1961) 253-267.

2. FARLEY, M. L., GREENBERG, S. D., SHUFORD, E. H., HURST, G. A., SPIVEY, C. G. and CHRISTIANSON, C. S. Ferruginous bodies in sputa of former asbestos workers. Acta cytol. 5 (1977) 693700 .

3. FONTANA, R. S. The Philadelphia pulmonary neoplasm research project. J. am. med. assoc. 225 (1973) 1373-1374.

4. FORD, D. K., FIDLER, H. K. and LOCK, D. R. Dysplastic lesion of the bronchial tree. Cancer 14 (1961) 1226-1234.

5. GARLAND, L. H. The rate of growth and apparent duration of untreated primary bronchial carcinoma. Cancer 16 (1963) 694-707.

6. GREENBERG, S. D., HURST, G. A., CHRISTIANSON, S. C., MATLAGE, W. J., HURST, I. J. and MARBY, L. C. Pulmonary cytopathology of former asbestos workers. Am. j. clin. pathol. 66 (1976) 815822.

7. HOURIHANE, D. O'B. and MC CAUGHEY, W. T. E. Pathological aspects of asbestosis. Postgrad. med. 42 (1966) 613-622. 
8. HUEPER, W. C. (ed.). Occupational and environmental cancer of the respiratory tract: Recent results in cancer research (vol. 3). Springer, Berlin 1966. 43 p.

9. INTERNATIONAL LABOR OFFICE. ILO $U / C$ international classification of pneumoconioses (Occupational safety and health series 22 (rev.)). Geneva 1972. 32 p.

10. JÄRVI, O. H., HORMIA, M. S., AUTIO, J. V. K., KANGAS, S. J. and TILVIS, P. K. Cytological diagnosis of pulmonary carcinoma in two hospitals. Acta cytol. 11 (1967) $477-482$.

11. JOHNSTON, W. W. and FRABLE, W. J. The cytopathology of the respiratory tract: A review. Am. j. pathol. 2 (1976): 84, 372414.

12. KANNERSTEIN, M. and CHURG, J. Pathology of carcinoma of the lung associated with asbestos exposure. Cancer 30 (1972) $14-21$.

13. KOSS, L. G., MELAMED, M. R. and GOODNER, J. T. Pulmonary cytology: A brief survey of diagnostic results from July 1st 1952 until December 31st, 1960. Acta cytol. 8 (1964) $104-113$.

14. MEURMAN, L., KIVILUOTO, R. and HAKAMA, M. Mortality and morbidity among the working population of anthophyllite asbestos miners in Finland. Br. $j$. ind. med. 31 (1974) 105-112.

15. NASIELL, M. Metaplasia and atypical metaplasia in the bronchial epithelium: A histopathologic and cytopathologic study. Acta cytol. 10 (1966) 421-427.

16. PEARSON, F. G., THOMPSON, D. W. and DELARUE, N. C. Experience with the cytologic detection, localisation and treatment of radiographically undemonstrable bronchial carcinoma. J. thorac. cardiovasc. surg. 54 (1967): 3, 371-382.

17. RHODES, M. L., BEDELL, G. N., KASIK, J. E., ZAVALA, D. and RICHARDSON, R. Early detection of lung cancer. Chest 64 (1973) $741-746$.

18. SACCOMANO, G., ARCHER, V. E., AUERBACH, O., SAUNDERS, R. P. and BRENNAN, L. M. Development of carcinoma of the lung as reflected in exfoliated cells. Cancer 33 (1974): 1, 256-270.

19. SASSY-DOBRAY, G. Possibilities of early diagnosis of bronchogenic carcinoma. Acta cytol. 19 (1975) 351-357.

20. SELIKOFF, I. J., HAMMOND, E. C. and CHURG, J. Asbestos exposure, smoking, and neoplasia. J. am. med. assoc. 204 (1968) $106-112$

21. SPENCER, H. (ed.). Pathology of the lung (2nd ed.). Pergamon Press, Oxford 1968. $788 \mathrm{p}$.

22. UMIKER, W. O. False-negative reports in the cytologic diagnosis of cancer of the lung. Am. j. clin. pathol. 28 (1957) 37-45.

23. VALENTINE, E. H. Squamous metaplasia of the bronchus: A study of metaplastic changes occurring in the epithelium of the major bronchi in cancerous and noncancerous cases. Cancer 10 (1957) 272-279.

24. WHITWELL, F., NEWHOUSE, M. L. and BENNET, D. R. A study of the histological cell types of lung cancer in workers suffering from asbestosis in the United Kingdom. Br. j. ind. med. 31 (1974) 298-303.

25. WOOLNER, L. B., ANDERSEN, H. A. and BERNATZ, P. E. "Occult" carcinoma of the bronchus: A study of 15 cases of in situ or early invasive bronchogenic carcinoma. Dis. chest 37 (1960) 278-288. 